Article

\title{
Architecture and Viability of the Biofilms Formed by Nine Listeria Strains on Various Hydrophobic and Hydrophilic Materials
}

\author{
Cristina Rodríguez-Melcón ${ }^{1,2}$, Carlos Alonso-Calleja ${ }^{1,2}$ and Rosa Capita ${ }^{1,2, *}$ \\ 1 Department of Food Hygiene and Technology, Veterinary Faculty, University of León, 24004 León, Spain \\ 2 Institute of Food Science and Technology, University of León, 24004 León, Spain \\ * Correspondence: rosa.capita@unileon.es; Tel.: +34-987-291-000 (ext. 5633); Fax: +34-987-293-073
}

Received: 15 September 2019; Accepted: 13 November 2019; Published: 3 December 2019

Featured Application: Graphene monolayer coatings may be of use in reducing biofilm formation by Listeria spp. in food-processing environments.

\begin{abstract}
Biofilms are a key factor in the persistence of Listeria in food processing plants, representing a potential source of foodstuff contamination. Nine Listeria strains (eight Listeria monocytogenes and one Listeria ivanovii) were studied by confocal laser scanning microscopy (CLSM) for their ability to form biofilm on glass, polystyrene, graphene and resin after $120 \mathrm{~h}$ of incubation at $12{ }^{\circ} \mathrm{C}$. The relationship between cell surface hydrophobicity and biofilm formation was also investigated. On comparing the data for all the strains, similar $(P>0.05)$ biovolume values were obtained on glass (average $\left.3.39 \pm 1.69 \mu \mathrm{m}^{3} / \mu \mathrm{m}^{2}\right)$ and graphene $\left(2.93 \pm 1.14 \mu \mathrm{m}^{3} / \mu \mathrm{m}^{2}\right)$, while higher $(P<0.05)$ values were observed for polystyrene $\left(4.39 \pm 4.14 \mu \mathrm{m}^{3} / \mu \mathrm{m}^{2}\right)$. The highest $(P<0.01)$ biovolume levels were found in the biofilms formed on resin $\left(7.35 \pm 1.45 \mu^{3} / \mu \mathrm{m}^{2}\right)$, which also had the smallest biomass of inactivated cells $\left(0.38 \pm 0.37 \mu \mathrm{m}^{3} / \mu \mathrm{m}^{2}\right.$ vs. $1.20 \pm 1.12 \mu \mathrm{m}^{3} / \mu \mathrm{m}^{2}$ on the remaining surfaces; $\left.P<0.001\right)$. No relationship was noted between cell surface hydrophobicity and biofilm-forming ability.
\end{abstract}

Keywords: Listeria monocytogenes; Listeria ivanovii; biofilm; cell surface hydrophobicity; glass; polystyrene; graphene; resin

\section{Introduction}

Listeriosis is a foodborne illness and the cause of approximately 23,000 infections in humans every year [1]. This disease is characterized by different clinical conditions such as gastroenteritis, meningoencephalitis, septicaemia, spontaneous abortion and serious infections in newborn babies. The groups most often affected are the young, the elderly, the immunocompromised, and pregnant women [2,3]. Listeriosis is a major problem because it exhibits a high fatality rate (of up to $30 \%$ ), requires hospital admission in more than $90 \%$ of cases, and has a neonatal death rate of $50 \%$ [4].

In 2017, 2480 confirmed cases of invasive listeriosis ( 0.48 cases per 100,000 population) were reported in the European Union, with a lethality rate of $13.8 \%$, the highest among all foodborne illnesses [5]. In the United States approximately 1600 cases of severe forms of human listeriosis occur each year (with an incidence rate of 0.26 cases per 100,000 population), with a lethality rate of over $16 \%$ [6]. Moreover, there is an upward trend in the prevalence of the illness, both in Europe and the United States $[5,7]$.

The Listeria family is made up of twenty different species [8]. Listeria monocytogenes is the one responsible for the vast majority of cases of human listeriosis, although some cases of human disease caused by Listeria ivanovii and Listeria seeligeri have been described $[9,10]$. L. monocytogenes is divided 
into thirteen different serotypes based on somatic and flagellar antigens, of which three $(1 / 2 a, 1 / 2 b, 4 b)$ are responsible for more than $90 \%$ of the cases of human illness worldwide [11,12].

L. monocytogenes can persist for years on equipment and installations in food industry facilities. This is mainly due to its capacity to survive and multiply under food-related conditions that are stressful for other bacteria, such as refrigeration temperatures, drying out, heat, high salt concentrations and extreme $\mathrm{pH}$ values, in addition to its ability to form biofilms [13]. Biofilms are structured microbial communities enclosed in a self-produced matrix of hydrated extracellular polymeric substances (EPS) that adhere to an inert or living surface [14]. Cells in biofilms become more resistant than planktonic cells to different environmental stress factors such as sanitizing agents, facilitating bacterial survival. Furthermore, biofilms can be a continuous source of contamination when in contact with foodstuffs, which can trigger human disease $[15,16]$.

Previous studies have suggested that the physical and chemical properties of the substratum, its surface characteristics, and environmental conditions may alter the structure and composition of bacterial biofilms [17]. L. monocytogenes can form biofilms on a range of surfaces [18], but in most previous research undertaken a single material has been used as a contact surface to study biofilms, most often glass, polystyrene or stainless steel. As far as we are aware, no previous studies have compared the architecture and viability of the biofilms formed by Listeria spp. at refrigeration temperatures on glass, polystyrene, graphene and resin. In general, polystyrene, graphene and resin are considered to be hydrophobic materials, while glass is hydrophilic [17,19-21].

Epoxy resins have been widely used for coatings, electronic materials, adhesives, and matrices for fibre-reinforced composites due to their outstanding mechanical properties, strong adhesive capacity, good ability to withstand heat, and high electrical and chemical resistance [22]. However, no previous studies have focused on the ability of pathogenic bacteria such as Listeria spp. to form biofilms on this material. Graphene, regarded as the thinnest material in the world, is a two-dimensional monolayer of carbon atoms tightly packed into a flat hexagonal structure like a honeycomb lattice [23]. Graphene is characterized by both antibacterial activity and low toxicity to human cells [24]. Nevertheless, the number of papers suggesting that graphene has a potential role in preventing the formation of biofilms is small [25]. To date, no papers have focused on the ability of graphene monolayers to inhibit biofilm formation by Listeria.

Cell surface hydrophobicity, which varies among strains, plays a role in the attachment of bacterial cells to abiotic surfaces [26,27]. It has been shown that there is a positive correlation between bacterial cell surface hydrophobicity and attachment to hydrophobic surfaces [28]. However, the relationships between capacities for initial attachment and biofilm formation among L. monocytogenes strains on abiotic surfaces remain unclear [29].

The aim of the present work was to compare the architecture and viability of biofilms formed by nine strains of Listeria spp. after $120 \mathrm{~h}$ of incubation at $12{ }^{\circ} \mathrm{C}$ on four surfaces, three of them hydrophobic (polystyrene, graphene and resin) and one hydrophilic (glass), using confocal laser scanning microscopy (CLSM). These materials were chosen because glass, polystyrene and resin are all widely employed in food-processing environments. In contrast, graphene is an innovative material for covering surfaces, and has been upto now less studied. The relationship between the surface hydrophobicity of bacterial cells and their ability to form biofilm on the various surfaces were also determined.

\section{Materials and Methods}

\subsection{Bacterial Strains and Culturing Conditions}

Eight L. monocytogenes (LM) strains and one L. ivanovii (LI) strain were analysed. These were LM26 (ATCC -American Type Culture Collection- 19112; serotype 1/2c), LM28 (ATCC 19111; serotype 1/2a), LM29 (ATCC 19114; serotype 4a), LM30 (ATCC 13932; serotype 4b), LM31 (STCC -Spanish Type Culture Collection- 936; serotype 1/2b), LM32 (STCC 937; serotype 3b), LM33 (STCC 938; serotype 3c), 
LM34 (ATCC 19117; serotype 4d) and LI ATCC 19119. The bacterial cultures were stored at $-50^{\circ} \mathrm{C}$ in tryptone soya broth (TSB, Oxoid Ltd., Hampshire, UK) with $20 \%$ (vol/vol) glycerol. Prior to each experiment, the strains were inoculated into TSB and incubated at $37^{\circ} \mathrm{C}$. After $24 \mathrm{~h}$ they were streaked onto tryptone soy agar (TSA, Oxoid) plates, which were incubated at $37^{\circ} \mathrm{C}$ for a further $24 \mathrm{~h}$ and then stored at $4{ }^{\circ} \mathrm{C}$ while the experiments were performed.

\subsection{Biofilm Formation}

The study of the formation and structure of the biofilms was carried out by CLSM using a previously described procedure [16]. CLSM combined with a quantitative analysis of the images that were obtained enabled numerical data to be collected for the structural parameters of biofilms, such as biovolume, facilitating the comparison of different biofilms by means of statistical analyses.

The strains were incubated in TSB for $24 \mathrm{~h}$ at $37^{\circ} \mathrm{C}$. Dilutions were then performed in the same culture broth until a concentration of $10^{6} \mathrm{cfu} / \mathrm{mL}$ was achieved. A volume of $125 \mu \mathrm{L}$ was added to wells of Corning ${ }^{\text {TM }}$ 96-Well Half Area High Content Imaging Glass Bottom Microplates (Fisher Scientific Ltd., Dublin, Ireland), and to wells of microtiter plates with a graphene monolayer coated bottom (Graphenea Headquarters, San Sebastian, Spain). A volume of $250 \mu \mathrm{L}$ was added to wells of Nunc ${ }^{\mathrm{TM}}$ MicroWell $^{\mathrm{TM}}$ 96-Well Optical-Bottom Plates with Polymer Base (Thermo Scientific ${ }^{\mathrm{TM}}$, SLU, Waltham, MA, USA), and to wells of microtiter plates with food safe epoxy resin coated bottoms (Résinence ${ }^{\circledR}$, Mormant-sur-Vernisson, France).

The microtiter plates were then incubated for $1 \mathrm{~h}$ at $12{ }^{\circ} \mathrm{C}$ to allow the microorganisms to adhere, and the wells rinsed once with $150 \mathrm{mM}$ sodium chloride ( $\mathrm{NaCl}$, Sigma-Aldrich Co., Saint Louis, MO, USA) to eliminate any bacterium that were not adhering. A volume of $125 \mu \mathrm{L}$ of sterile TSB was then added in the case of the glass and graphene surfaces, and $250 \mu \mathrm{L}$ in the case of the polystyrene and resin. The plates were then incubated under static conditions without culture medium renewal for $120 \mathrm{~h}$ at $12^{\circ} \mathrm{C}$.

Two dyes were used, SYTO9 and propidium iodide (PI). The first emits green fluorescence during CLSM imaging and is used to identify living microorganisms with an intact membrane. The second emits red fluorescence, which stains dead bacteria with damaged membranes. A volume of $2.0 \mu \mathrm{L}$ of a 1:1 mixture of SYTO9 (stock $3.34 \mathrm{mM}$ in DMSO) and PI (stock $20 \mathrm{mM}$ in DMSO) fluorescent dyes from the BacLight Bacterial Viability Kit (Invitrogen, Carlsbad, CA, USA) was added to $1000 \mu \mathrm{L}$ of TSB, and a measured quantity of the resultant solution was added to each well: $125 \mu \mathrm{L}$ for the glass and graphene, and $250 \mu \mathrm{L}$ for the polystyrene and resin. The plate was then incubated in the dark at $37^{\circ} \mathrm{C}$ for $20 \mathrm{~min}$ to enable the fluorescent labelling of the bacteria.

CLSM imaging was performed using a Zeiss LSM 800 Airyscan confocal laser scanning microscope with ZEN 2.3 software (Carl Zeiss, Jena, Germany). Channel mode visualization was performed using the $63 \times(0.8 \mathrm{NA})$ objective with oil immersion. Table 1 shows the microscope parameters used.

Table 1. Stains and microscope parameters used in studying Listeria spp. biofilms.

\begin{tabular}{ccc}
\hline & \multicolumn{2}{c}{ Dye } \\
\hline Parameter & SYTO 9 & Propidium Iodide \\
\hline Pinhole & $44 \mu \mathrm{m}$ & $44 \mu \mathrm{m}$ \\
Laser Wavelength & $488 \mathrm{nm:} \mathrm{0.20 \%}$ & $561 \mathrm{~nm}: 0.20 \%$ \\
Excitation Wavelength & $483 \mathrm{~nm}$ & $305 \mathrm{~nm}$ \\
Emission Wavelength & $500 \mathrm{~nm}$ & $617 \mathrm{~nm}$ \\
Detection Wavelength & $450-560 \mathrm{~nm}$ & $560-700 \mathrm{~nm}$ \\
Imaging Device & LSM $800 /$ GaAsP-Pmt2 & LSM 800/Airyscan \\
Detector & GaAsP & Airyscan \\
Detector Gain & $700 \mathrm{~V}$ & $700 \mathrm{~V}$ \\
\hline
\end{tabular}


Three stacks of horizontal plane images ( $512 \times 512$ pixels corresponding to $126.8 \times 126.8 \mu \mathrm{m})$ with a z-step of $1.0 \mu \mathrm{m}$ were acquired for each well from three different randomly chosen areas. Three independent experiments were performed for each strain and surface material. Thus, a total of 324 CLSM images were obtained ( 9 strains $\times 4$ surface materials $\times 3$ replicates $\times 3$ surfaces in each well). The original Zeiss files (CZI format) were imported into the IMARIS 9.1 software package (Bitplane, Zurich, Switzerland) to analyse the images [16].

\subsection{Determination of Cell Surface Hydrophobicity}

The cell surface hydrophobicity (CSH) of the bacteria was determined by the microbial adhesion to solvents (MATS) test based on their affinity to non-polar solvents [30]. Xylene was used as the hydrocarbon phase. Listeria cells were grown in TSB for $24 \mathrm{~h}$ at $37^{\circ} \mathrm{C}$. The cells were harvested twice by centrifuging $\left(3200 \times g, 10 \mathrm{~min}, 4^{\circ} \mathrm{C}\right.$ ) and washed with sterile PBS (Merck KGaA, Darmstadt, Germany). The cells were re-suspended in TSB at an initial concentration of $10^{5} \mathrm{cfu} / \mathrm{mL}$. After $24 \mathrm{~h}$ at $37^{\circ} \mathrm{C}$, the cells were centrifuged, washed twice with PBS, and re-suspended in $150 \mathrm{mM} \mathrm{NaCl}$ at a concentration of $10^{8} \mathrm{cfu} / \mathrm{mL}$. An aqueous-phase sample $(0.4 \mathrm{~mL})$ was obtained, and the optical density at $405 \mathrm{~nm}\left(\mathrm{OD}_{405}\right)$ was determined (Bioscreen C MBR, Oy Growth Curves Ab Ltd., Helsinki, Finland). The cell suspension $(2.0 \mathrm{~mL}$ ) was vortexed with $0.33 \mathrm{~mL}$ of xylene (Merck KGaA, Darmstadt, Germany) for $60 \mathrm{~s}$ and then allowed to stand for $15 \mathrm{~min}$ at room temperature, thus completely separating the two phases. The percentage of cells present in the solvent was calculated using the following equation: $\%$ affinity to xylene $=100 \times[1-(A / A 0)]$, where $A 0$ is the $\mathrm{OD}_{405}$ of the original suspension prior to mixing, and $A$ is the $\mathrm{OD}_{405}$ of the aqueous phase. The cell surface hydrophobicity was grouped into three categories: weak $(<21 \%)$, moderate $(21 \%$ to $50 \%)$, and strong $(>50 \%)$ affinities for xylene [30]. All the determinations were carried out eight times over four separate days (twice on each day).

\subsection{Statistical Analysis}

The quantitative structural parameters of the biofilms and the percentages of affinity for xylene were compared for statistical significance using one-way analysis of variance (ANOVA) techniques. Mean separations were obtained using Duncan's multiple-range test. All the data processing in this study was carried out using the Statistica ${ }^{\circledR} 8.0$ software package (Statsoft Ltd., Tulsa, OK, USA). Significant differences were established for a probability level of $5 \%(P<0.05)$.

\section{Results}

\subsection{Biofilm Determination}

The three-dimensional images of the biofilms formed by nine Listeria strains on various contact surfaces (glass, polystyrene, graphene and resin) are shown in Figure 1. On resin, all the strains produced compact structures that covered the entire available surface area. However, a strong strain-to-strain variation in the three-dimensional biofilm structures was observed on glass, polystyrene and graphene. On these materials some strains (LM28, LM29, LM32, LM33 and LI) formed biofilms containing several small aggregates, while others (LM26, LM30, LM31 and LM34) produced rough biofilms with a patchy coverage and confluent growth areas where the bacterium formed clumps. 




Figure 1. Three-dimensional projections of the biofilm structures of nine Listeria spp. isolates on four materials (glass, polystyrene, graphene monolayer coating and epoxy resin coating). The biofilms were studied after $120 \mathrm{~h}$ of incubation at $12{ }^{\circ} \mathrm{C}$. The images $(126.8 \mu \mathrm{m} \times 126.8 \mu \mathrm{m})$ were reconstructed from confocal z-stacks using IMARIS software, with shadow projections to the right.

The numerical data confirmed the visual observations. Figure 2 shows the box and whisker diagrams of the distribution of the biovolume values (total biovolume, biovolume for live cells, and biovolume for dead cells) found for each strain and surface material. Major differences were observed between strains $(P<0.001)$ with respect to their capacity to form biofilm. Considering the data for the four materials simultaneously, the total biovolume varied from $2.61 \pm 1.93 \mu \mathrm{m}^{3} / \mu \mathrm{m}^{2}$ for LM33 to $8.37 \pm 3.11 \mu \mathrm{m}^{3} / \mu \mathrm{m}^{2}$ for LM34. The biovolume of live cells ranged from $2.09 \pm 2.06 \mu \mathrm{m}^{3} / \mu \mathrm{m}^{2}$ 
for LM33 to $6.32 \pm 2.40 \mu \mathrm{m}^{3} / \mu \mathrm{m}^{2}$ for LM34, while the biovolume of inactivated cells ranged from $0.52 \pm 0.41 \mu \mathrm{m}^{3} / \mu \mathrm{m}^{2}$ for LM33 to $2.51 \pm 1.98 \mu \mathrm{m}^{3} / \mu^{2}$ for LM34.
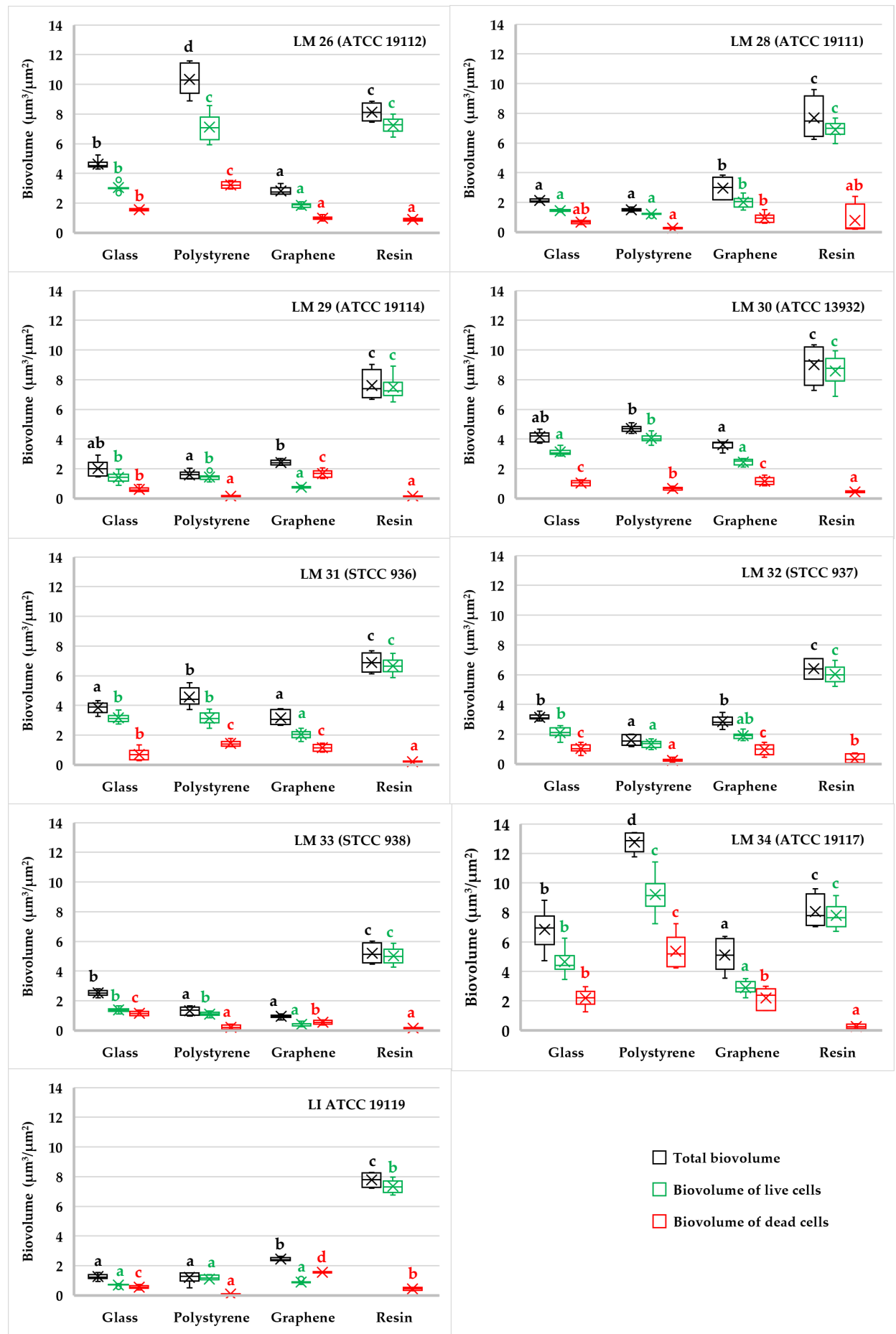

Figure 2. Box and whisker diagrams showing the distribution of the biovolume values observed for eight L. monocytogenes (LM) strains and one L. ivanovii (LI) strain. The boxes run from the 25th to the 75th percentile and are intersected by the median line. Whiskers extend below the box range, from the lowest to the highest values, respectively. Average values are indicated with $(\times)$. Outliers are indicated as individual data points $(\bigcirc)$. Average values in the same graph for the same physiological state (total, live or dead cells) with no letter in common are significantly different $(P<0.05)$. In total, nine determinations were performed for each strain, contact material and physiological state. 
Similar values $(P>0.05)$ for total biovolume were observed in the biofilms formed on glass (average $\left.3.39 \pm 1.69 \mu \mathrm{m}^{3} / \mu \mathrm{m}^{2}\right)$ and graphene monolayer coating $\left(2.93 \pm 1.14 \mu \mathrm{m}^{3} / \mu \mathrm{m}^{2}\right)$. These figures were lower $(P<0.05)$ than those recorded for polystyrene $\left(4.39 \pm 4.14 \mu \mathrm{m}^{3} / \mu \mathrm{m}^{2}\right)$. The greatest biovolume $(P<0.01)$ was found on the epoxy resin coating $\left(7.35 \pm 1.45 \mu \mathrm{m}^{3} / \mu \mathrm{m}^{2}\right)$. There were also differences among groups of samples $(P<0.01)$ when only the live cells were considered, with the greatest biovolume found for biofilms formed on resin $\left(6.97 \pm 1.33 \mu \mathrm{m}^{3} / \mu \mathrm{m}^{2}\right)$, followed by those formed on polystyrene $\left(3.30 \pm 2.92 \mu \mathrm{m}^{3} / \mu^{2}\right)$. The biofilms produced on the glass and graphene surfaces showed similar values $(P>0.05)$ for biovolume $\left(2.33 \pm 1.25 \mu \mathrm{m}^{3} / \mu \mathrm{m}^{2}\right.$ and $1.69 \pm 0.83 \mu \mathrm{m}^{3} / \mu \mathrm{m}^{2}$, respectively). Regarding the biovolume of inactivated cells, the amount was lower $(P<0.001)$ in the biofilms on resin $\left(0.38 \pm 0.37 \mu \mathrm{m}^{3} / \mu \mathrm{m}^{2}\right)$ than in those formed on glass, polystyrene and graphene $\left(1.06 \pm 0.57 \mu \mathrm{m}^{3} / \mu \mathrm{m}^{2}, 1.30 \pm 1.78 \mu \mathrm{m}^{3} / \mu \mathrm{m}^{2}\right.$ and $1.24 \pm 0.56 \mu \mathrm{m}^{3} / \mu \mathrm{m}^{2}$, respectively; $\left.P>0.05\right)$.

Differences were noted between strains with respect to their preference for the different materials (Figure 2). All the strains formed the greatest amount of biofilm on resin except for strains LM26 and LM34, which produced biofilms with the greatest biovolume on polystyrene. The smallest biomass of biofilm for most of the strains (LM26, LM30, LM31, LM33 and LM34) was found on graphene.

The biofilms in general were mostly made up of living cells. The exceptions were the biofilms produced by three strains (LM29, LM33 and LI) on the graphene surfaces, where inactivated bacteria predominated.

\subsection{Cell Surface Hydrophobicity}

Substantial differences $(P<0.001)$ were observed between the values for hydrophobicity obtained for the various strains of Listeria spp. The percentage of affinity for xylene ranged from $4.84 \pm 1.11 \%$ in the case of LM26 to $31.82 \pm 5.98 \%$ for LM34 (Figure 3). Six strains (66.7\% of the total) had weak reactions ( $<21 \%$ affinity for xylene) and a further three strains $(23.3 \%)$ showed moderate reactions (between $21 \%$ and $50 \%$ affinity for xylene). No relationship was found between hydrophobicity and the ability to form biofilms on the various materials tested.

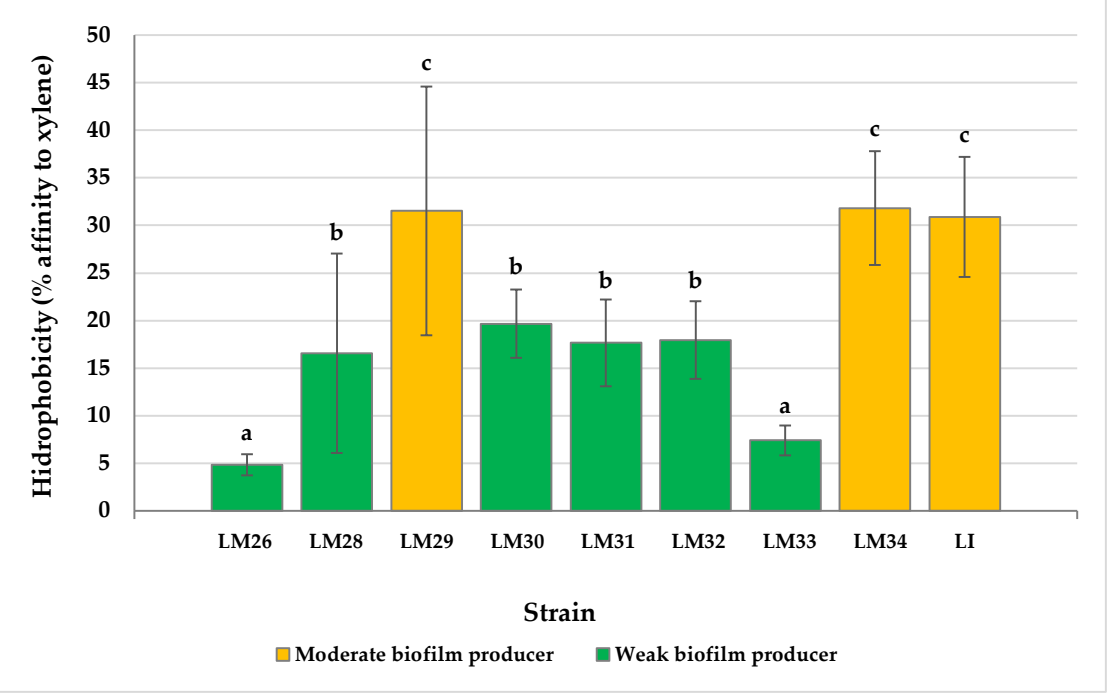

Figure 3. Cell surface hydrophobicity values observed for cultures of eight Listeria monocytogenes (LM) strains and one Listeria ivanovii (LI) strain. Data are means \pm standard deviations (SD) for eight determinations. Mean values with no letters in common are significantly different $(P<0.05)$. LM26 (ATCC-American Type Culture Collection- 19112; serotype 1/2c), LM28 (ATCC 19111; serotype 1/2a), LM29 (ATCC 19114; serotype 4a), LM30 (ATCC 13932; serotype 4b), LM31 (STCC-Spanish Type Culture Collection- 936; serotype 1/2b), LM32 (STCC 937; serotype 3b), LM33 (STCC 938; serotype 3c), LM34 (ATCC 19117; serotype 4d), LI (ATCC 19119). 


\section{Discussion}

Biofilm formation by Listeria spp. in food processing environments is a serious threat for the food industry since these structures contribute to the persistence of microorganisms, increasing the risk of contamination of foodstuffs [30]. The ability of Listeria to produce biofilms at the low temperatures used during food processing and storage (for example, $12^{\circ} \mathrm{C}$ ) increases the likelihood of cross-contamination.

In line with previous findings [19,31-35], all the strains of Listeria tested showed a capacity to form biofilms under the conditions studied. Nevertheless, a strong strain-to-strain variation in biofilm-forming ability was observed (Figure 1). An intra-specific variability in biofilm architecture has also been reported by other authors. Among the different structures seen are one-cell-thick layers, flat layers of cells consisting of several layers without a given structure, honeycomb structures, and networks of interwoven clumps [35-42]. The great variability observed in the structure of the biofilms formed by Listeria spp. shows that there is a clear need to assay various strains when drawing conclusions about the ability of these bacteria to produce biofilm.

The three-dimensional images obtained show marked variations in the structure of the biofilms depending on the contact material. While on resin all the strains formed robust biofilms covering the entire surface, on glass, polystyrene and graphene the biofilms produced were more irregular, consisting of just small clumps of cells in some cases. The smallest production of biofilm was found on glass and especially graphene. It is noteworthy that the greater the amount of biofilm, the greater the likelihood of cross-contamination.

Other studies have also recorded major differences between contact surfaces when investigating the formation of biofilms by L. monocytogenes. In previous research [19] undertaken using a strain of L. monocytogenes of food origin (LM6), it was observed that the biofilms formed at $37^{\circ} \mathrm{C}$ showed greater biovolume on glass surfaces than on polystyrene. It must be pointed out that this strain had low hydrophobicity (14.8\% affinity for xylene), which may explain its limited attachment to the hydrophobic surfaces. Bonsaglia et al. [43] observed biofilm formation at $4{ }^{\circ} \mathrm{C}$ on different surfaces, with greater amounts of biofilm recorded on stainless steel and glass than on polystyrene. Using the crystal violet assay technique, Di Bonaventura et al. [44] also observed that L. monocytogenes was able to form biofilms at $4{ }^{\circ} \mathrm{C}$ and $12{ }^{\circ} \mathrm{C}$, producing greater amounts on glass than on the more hydrophobic stainless steel and polystyrene. The aforementioned results do not coincide with the findings of the present study, in which the greatest production of biofilm was observed on the hydrophobic materials, resin and polystyrene. Intraspecific variations in the behaviour of L. monocytogenes could be responsible for the differences found between reports.

Some researchers have demonstrated that the hydrophobicity of the microbial cell surface plays a critical role in the adherence of bacteria to hydrophobic surfaces like polystyrene $[45,46]$. Because bacterial adhesion to the surface is the first step in biofilm formation, it is to be expected that an increase in cell surface hydrophobicity should be accompanied by a greater bacterial ability to form biofilms on abiotic surfaces [28,47,48]. However, controversial results for the effects of cell surface hydrophobicity on biofilm formation on cell contact surfaces have been reported because biofilm formation depends on several factors [49], such as temperature. To this effect, it has been observed that biofilm formation is greater at temperatures above $20^{\circ} \mathrm{C}$ than at refrigeration temperatures, for example $12{ }^{\circ} \mathrm{C}$, the temperature used in this study [15,44,50,51].

The results reported here, where no relationship was observed between the percentage of affinity to xylene and the biomass of biofilms, suggest that biofilm formation in Listeria spp. is regulated by factors other than hydrophobicity, depending on the strain. This conclusion is corroborated by the fact that some strains (LM29 and LI) presented high values for hydrophobicity but sparse biofilm formation on both the hydrophilic (glass) and the hydrophobic (polystyrene and graphene) surfaces. In contrast, LM26 presented low hydrophobicity together with a high capacity to form biofilm on all four surfaces, and markedly so on polystyrene. Along these lines, Di Bonaventura et al. [44] stated that biofilm formation by different strains of Listeria spp. on glass was weakly correlated with the hydrophobicity of bacterial surfaces, coinciding with the results obtained in the present study. Likewise, previous 
research [30] has found weak hydrophobicity but extensive surface coverage in biofilms formed by strains of Escherichia coli on polystyrene. However, comparisons between reports should be made with caution because the hydrophobic surface properties of bacterial cells can be modified by several factors such as the characteristics of the culture medium, growth conditions and the study methods used [48,52].

Importantly, the biofilms with the smallest biovolume were produced on graphene surfaces. These results suggest that graphene monolayer coatings may contain surface properties that reduce the formation of biofilm, as has been suggested by other authors [21,53].

\section{Conclusions}

Biofilms of Listeria spp. are a major challenge for the food industry and the health system. Knowledge of the influence of various factors such as the contact material on the architecture and viability of biofilms is essential to optimize strategies to control these structures. The results of this study demonstrate that the material plays a significant role in the formation of biofilms by Listeria strains. The biofilms attained their greatest biovolume on resin, followed by polystyrene, suggesting that these materials are not suitable for preventing biofilm formation by Listeria spp. On glass, and above all on graphene, the biofilms produced had a smaller biovolume, so graphene monolayer coatings may be of practical use in reducing biofilm formation by Listeria. No relationship was observed between cell surface hydrophobicity and the biofilm-forming ability of Listeria spp. on abiotic surfaces. The present research adds to the knowledge of the biofilm-forming process by L. monocytogenes and L. ivanovii at refrigeration temperatures. Nonetheless, the results obtained were based on laboratory experiments and additional research under real-life conditions would be required to confirm these findings.

Author Contributions: Conceptualization, C.A.-C. and R.C.; data curation, C.R.-M. and R.C.; formal analysis, C.A.-C. and R.C.; funding acquisition, C.A.-C. and R.C.; investigation, C.R.-M., C.A.-C. and R.C.; methodology, C.R.-M. and R.C.; project administration, C.A.-C.; resources, C.A.-C. and R.C.; software, R.C.; supervision, C.A.-C.; validation, C.R.-M., C.A.-C. and R.C.; visualization, R.C.; writing-original draft, C.R.-M., C.A.-C. and R.C.; writing-review and editing, C.A.-C. and R.C.

Funding: This research was funded by the Ministerio de Ciencia, Innovación y Universidades (Spain, Project RTI2018-098267-R-C33) and by the Junta de Castilla y León (Consejería de Educación, Spain, Project LE164G18).

Conflicts of Interest: The authors declare no conflict of interest.

\section{References}

1. Rothrock, M.J.; Micciche, A.C.; Bodie, A.R.; Ricke, S.C. Listeria occurrence and potential control strategies in alternative and conventional poultry processing and retail. Front. Sust. Food Syst. 2019, 3, 33. [CrossRef]

2. Davis, M.L.; Ricke, S.C.; Donalson, J.R. Establishment of Listeria monocytogenes in the gastrointestinal tract. Microorganisms 2019, 7, 75. [CrossRef] [PubMed]

3. Lanciotti, R.; Braschi, G.; Patrignani, F.; Gobbetti, M.; De Angelis, M. How Listeria monocytogenes shapes its proteome in response to natural antimicrobial compounds. Front. Microbiol. 2019, 10, 437. [CrossRef] [PubMed]

4. Doijad, S.P.; Barbuddhe, S.B.; Garg, S.; Poharkar, K.V.; Kalorey, D.R.; Kurkure, N.V.; Rawool, D.B.; Chakraborty, T. Biofilm-forming abilities of Listeria monocytogenes serotypes isolated from different sources. PLoS ONE 2015, 10, e0137046. [CrossRef] [PubMed]

5. EFSA; ECDC. The European Union summary report on trends and sources of zoonoses, zoonotic agents and food-borne outbreaks in 2017. EFSA J. 2018, 16, e05500. [CrossRef]

6. CDC. Listeria (listeriosis). Centers for Disease Control and Prevention. Available online: https://www.cdc. gov/listeria/index.html (accessed on 14 September 2019).

7. Pohl, A.M.; Pouillot, R.; Van Doren, J.M. Changing US population demographics: What does this mean for listeriosis incidence and exposure? Foodborne Pathog. Dis. 2017, 14, 524-530. [CrossRef]

8. Leclercq, A.; Moura, A.; Vales, G.; Tessaud-Rita, N.; Aguilhon, C.; Lecuit, M. Listeria thailandensis sp. nov. Int. J. Syst. Microbiol. 2019, 69, 74-81. [CrossRef] 
9. Wagner, M.; McLauchlin, J. Biology. In Handbook of Listeria Monocytogenes; Dongyou, L., Ed.; CRC Press: Boca Raton, FL, USA, 2008; pp. 3-25.

10. Orsi, R.H.; Wiedmann, M. Characteristics and distribution of Listeria spp., including Listeria species newly described since 2009. Appl. Microbiol. Biotechnol. 2016, 100, 5273-5287. [CrossRef]

11. Shi, W.; Quingping, W.; Jumei, Z.; Moutong, C.; Zéan, Y. Prevalence, antibiotic resistance and genetic diversity of Listeria monocytogenes isolated from retail ready-to-eat foods in China. Food Control 2015, 47, 340-347. [CrossRef]

12. Capita, R.; Felices-Mercado, A.; García-Fernández, C.; Alonso-Calleja, C. Characterization of Listeria monocytogenes originating from the Spanish meat-processing chain. Foods 2019, 8, 542. [CrossRef]

13. Rodríguez-López, P.; Rodríguez-Herrera, J.J.; Vázquez-Sánchez, D.; López-Cabo, M. Current knowledge on Listeria monocytogenes biofilms in food-related environments: Incidence, resistance to biocides, ecology and biocontrol. Foods 2018, 7, 85. [CrossRef] [PubMed]

14. González-Rivas, F.; Ripolles-Avila, C.; Fontecha-Umaña, F.; Ríos-Castillo, A.G.; Rodríguez-Jerez, J.J. Biofilms in the spotlight: Detection, quantification and elimination at a food industry level. Comp. Rev. Food Sci. Food Saf. 2018, 17, 1261-1276. [CrossRef]

15. Piercey, M.J.; Ells, T.C.; Macintosh, A.J.; Hansen, L.T. Variations in biofilm formation, desiccation resistance and benzalkonium chloride susceptibility among Listeria monocytogenes strains isolated in Canada. Int. J. Food Microbiol. 2017, 257, 254-261. [CrossRef]

16. González-Machado, C.; Capita, R.; Riesco-Peláez, F.; Alonso-Calleja, C. Visualization and quantification of the cellular and extracellular components of Salmonella Agona biofilms at different stages of development. PLoS ONE 2018, 13, e0200011. [CrossRef] [PubMed]

17. Liang, X.; Peng, L.-H.; Zhang, S.; Zhou, S.; Yoshida, A.; Osatomi, K.; Bellou, N.; Guo, X.-P.; Dobretsov, S.; Yang, J.-L. Polyurethane, epoxy resin and polydimethylsiloxane altered biofilm formation and mussel settlement. Chemosphere 2019, 218, 599-608. [CrossRef]

18. Galié, S.; García-Gutiérrez, C.; Miguélez, E.M.; Villar, C.J.; Lombó, F. Biofilms in the food industry: Health aspects and control methods. Front. Microbiol. 2018, 9, 898. [CrossRef]

19. Rodríguez-Melcón, C.; Riesco-Peláez, F.; Carballo, J.; García-Fernández, C.; Capita, R.; Alonso-Calleja, C. Structure and viability of 24- and 72-h-old biofilms formed by four pathogenic bacteria on polystyrene and glass contact surfaces. Food Microbiol. 2018, 76, 513-517. [CrossRef]

20. Ben Abdallah, F.; Lagha, R.; Said, K.; Kallel, H.; Gharbi, J. Detection of cell surface hydrophobicity, biofilm and fimbriae genes in Salmonella isolated from Tunisian clinical and poultry meat. Iran J. Public Health 2014, 43, 423-431.

21. Yilbas, B.S.; Ibrahim, A.; Ali, H.; Khaled, M.; Laoui, T. Hydrophobic and optical characteristics of graphene and graphene oxide films transferred onto functionalized silica particles deposited glass surface. Appl. Surf. Sci. 2018, 442, 213-223. [CrossRef]

22. Jin, F.-L.; Li, X.; Park, S.-J. Synthesis and application of epoxy resins: A review. J. Ind. Eng. Chem. 2015, 29, 1-11. [CrossRef]

23. Kurantowicz, N.; Sawosz, E.; Jaworski, S.; Kutwin, M.; Strojny, B.; Wierzbicki, M.; Szeliga, J.; Hotowy, A.; Lipińska, L.; Koziński, R.; et al. Interaction of graphene family materials with Listeria monocytogenes and Salmonella enterica. Nanoscale Res. Lett. 2015, 10, 23. [CrossRef] [PubMed]

24. Szunerits, S.; Boukherroub, R. Antibacterial activity of graphene-based materials. J. Mater. Chem. B 2016, 4, 6892-6912. [CrossRef]

25. Dybowska-Sarapuk, Ł.; Kotela, A.; Krzemiński, J.; Wróblewska, M.; Marchel, H.; Romaniec, M.; Łęgosz, P.; Jakubowska, M. Graphene nanolayers as a new method for bacterial biofilm prevention: Preliminary results. J. AOAC Int. 2017, 100, 900-904. [CrossRef] [PubMed]

26. Choi, N.-Y.; Bae, Y.M.; Lee, S.-Y. Cell surface properties and biofilm formation of pathogenic bacteria. Food Sci. Biotechnol. 2015, 24, 2257-2264. [CrossRef]

27. Colagiorgi, A.; Bruini, I.; Di Ciccio, P.A.; Zanardi, E.; Ghidini, S.; Ianieri, A. Listeria monocytogenes biofilms in the wonderland of Food Industry. Pathogens 2017, 6, 41. [CrossRef]

28. Takahashi, H.; Suda, T.; Tanaka, Y.; Kimura, B. Cellular hydrophobicity of Listeria monocytogenes involves initial attachment and biofilm formation on the surface of polyvinyl chloride. Lett. Appl. Microbiol. 2010, 50, 618-625. [CrossRef] 
29. Lee, B.-H.; Hébraud, M.; Bernardi, T. Increased adhesion of Listeria monocytogenes strains to abiotic surfaces under cold stress. Front. Microbiol. 2017, 8, 2221. [CrossRef]

30. Capita, R.; Riesco-Peláez, F.; Alonso-Hernando, A.; Alonso-Calleja, C. Exposure of Escherichia coli ATCC 12806 to sublethal concentrations of food-grade biocides influences its ability to form biofilm, resistance to antimicrobials, and ultrastructure. Appl. Environ. Microbiol. 2014, 80, 1268-1280. [CrossRef]

31. Ripolles-Avila, C.; Hascoët, A.S.; Guerrero-Navarro, A.E.; Rodríguez-Jerez, J.J. Establishment of incubation conditions to optimize the in vitro formation of mature Listeria monocytogenes biofilms on food-contact surfaces. Food Control 2018, 92, 240-248. [CrossRef]

32. Rodríguez-Melcón, C.; Capita, R.; García-Fernández, C.; Alonso-Calleja, C. Effects of Bacteriophage P100 at different concentrations on the structural parameters of Listeria monocytogenes biofilms. J. Food Prot. 2018, 81, 2040-2044. [CrossRef]

33. Ripolles-Avila, C.; Cervantes-Huaman, B.H.; Hascoët, A.S.; Yuste, J.; Rodríguez-Jerez, J.J. Quantification of mature Listeria monocytogenes biofilms: A comparison of different methods. Int. J. Food Microbiol. 2019, 289, 209-214. [CrossRef] [PubMed]

34. Rodríguez-Melcón, C.; Capita, R.; Rodríguez-Jerez, J.J.; Martínez-Suárez, J.V.; Alonso-Calleja, C. Effect of low doses of disinfectants on the biofilm-forming ability of Listeria monocytogenes. Foodborne Pathog. Dis. 2019, 16, 262-268. [CrossRef] [PubMed]

35. Rodríguez-Melcón, C.; Riesco-Peláez, F.; García-Fernández, C.; Alonso-Calleja, C.; Capita, R. Susceptibility of Listeria monocytogenes planktonic cultures and biofilms to sodium hypochlorite and benzalkonium chloride. Food Microbiol. 2019, 82, 533-540. [CrossRef] [PubMed]

36. Norwood, D.E.; Gilmour, A. Adherence of Listeria monocytogenes strains to stainless steel coupons. J. Appl. Microbiol. 1999, 86, 576-582. [CrossRef]

37. Marsh, E.J.; Luo, H.; Wang, H. A three-tiered approach to differentiate Listeria monocytogenes biofilm-forming abilities. FEMS Microbiol. Lett. 2003, 228, 203-210. [CrossRef]

38. Mosquera-Fernández, M.; Rodríguez-López, P.; Cabo, M.L.; Balsa-Canto, E. Numerical spatio-temporal characterization of Listeria monocytogenes biofilms. Int. J. Food Microbiol. 2014, 182, 26-36. [CrossRef]

39. Guilbaud, M.; Piveteau, P.; Desvaux, M.; Brisse, S.; Briandet, R. Exploring the diversity of Listeria monocytogenes biofilm architecture by high-throughput confocal laser scanning microscopy and the predominance of the honeycomb-like morphotype. Appl. Environ. Microbiol. 2015, 81, 1813-1819. [CrossRef]

40. Reis-Teixeira, F.B.D.; Alves, V.F.; de Martinis, E.C.P. Growth, viability and architecture of biofilms of Listeria monocytogenes formed on abiotic surfaces. Braz. J. Microbiol. 2017, 48, 587-591. [CrossRef]

41. Pang, X.; Wong, C.; Chung, H.-J.; Yuk, H.-G. Biofilm formation of Listeria monocytogenes and its resistance to quaternary ammonium compounds in a simulated salmon processing environment. Food Control 2019, 98, 200-208. [CrossRef]

42. Alonso-Calleja, C.; Gómez-Fernández, S.; Carballo, J.; Capita, R. Prevalence, molecular typing and determination of the biofilm-forming ability of Listeria monocytogenes serotypes from poultry meat and poultry preparations in Spain. Microorganisms 2019, 7, 529. [CrossRef]

43. Bonsaglia, E.C.R.; Silva, N.C.C.; Fernandes, A.; Araújo, J.P.; Tsunemi, M.H.; Rall, V.L.M. Production of biofilm by Listeria monocytogenes in different materials and temperatures. Food Control 2014, 35, 386-391. [CrossRef]

44. Di Bonaventura, G.; Piccolomini, R.; Paludi, D.; D’Orio, V.; Vergara, A.; Conter, M.; Ianieri, A. Influence of temperature on biofilm formation by Listeria monocytogenes on various food-contact surfaces: Relationship with motility and cell surface hydrophobicity. J. Appl. Microbiol. 2008, 104, 1552-1561. [CrossRef] [PubMed]

45. Gallardo-Moreno, A.M.; González-Martín, M.L.; Pérez-Giraldo, C.; Bruque, J.M.; Gómez-García, A.C. Serum as a factor influencing adhesion of Enterococcus faecalis to glass and silicone. Appl. Environ. Microbiol. 2002, 68, 5784-5787. [CrossRef] [PubMed]

46. Gallardo-Moreno, A.M.; González-Martín, M.L.; Pérez-Giraldo, C.; Garduno, E.; Bruque, J.M.; Gómez-García, A.C. Thermodynamic analysis of growth temperature dependence in the adhesion of Candida parapsilosis to polystyrene. Appl. Environ. Microbiol. 2002, 68, 2610-2613. [CrossRef] [PubMed]

47. Norouzi, F.; Mansouri, S.; Moradi, M.; Razavi, M. Comparison of cell surface hydrophobicity and biofilm formation among ESBL- and non-ESBL-producing Pseudomonas aeruginosa clinical isolates. Afr. J. Microbiol. Res. 2010, 4, 1143-1147.

48. Patel, J.; Sharma, M.; Ravishakar, S. Effect of curli expression and hydrophobicity of Escherichia coli O157:H7 on attachment to fresh produce surfaces. J. Appl. Microbiol. 2011, 110, 737-745. [CrossRef] 
49. Dourou, D.; Beauchamp, C.S.; Yoon, Y.; Geornaras, I.; Belk, K.E.; Smith, G.C.; Nychas, G.-J.E.; Sofos, J.N. Attachment and biofilm formation by Escherichia coli O157:H7 at different temperatures, on various food-contact surfaces encountered in beef processing. Int. J. Food Microbiol. 2011, 149, 262-268. [CrossRef]

50. Chavant, P.; Martinie, B.; Meylheuc, T.; Bellon-Fontaine, M.N.; Hebraud, M. Listeria monocytogenes LO28: Surface physicochemical properties and ability to form biofilms at different temperatures and growth phases. Appl. Environ. Microbiol. 2002, 68, 728-737. [CrossRef]

51. Piercey, M.J.; Hingston, P.A.; Hansen, T.L. Genes involved in Listeria monocytogenes biofilm formation at a simulated food processing plant temperature of $15^{\circ}$ C. Int. J. Food Microbiol. 2016, 223, 63-74. [CrossRef]

52. Tomičić, R.M.; Čabarkapa, I.S.; Vukmirović, Đ.M.; Lević, J.D.; Tomičić, Z.M. Influence of growth conditions on biofilm formation of Listeria monocytogenes. Food Feed Res. 2016, 43, 19-24. [CrossRef]

53. Dong, H.S.; Qi, S.J. Realising the potential of graphene-based materials for biosurfaces-A future perspective. Biosurf. Biotribol. 2015, 1, 229-248. [CrossRef]

(C) 2019 by the authors. Licensee MDPI, Basel, Switzerland. This article is an open access article distributed under the terms and conditions of the Creative Commons Attribution (CC BY) license (http://creativecommons.org/licenses/by/4.0/). 